\title{
THE GAS EXCHANGE PARAMETERS OF Abies balsamea (L) MILL. AND Abies concolor SAPLINGS, GROWN UNDER VARIOUS WATER REGIME, EXPOSED TO EXTREME DROUGHT STRESS AT THE END OF THE GROWING SEASON
}

\author{
İsmail KOÇ* \\ Forestry Vocational School, Düzce University, 81620, Düzce \\ *Corresponding author: ismailkoc@duzce.edu.tr
}

İsmail KOÇ: https://orcid.org/0000-0001-5847-9155

Please cite this article as: Koç, İ. (2021) Examination of gas exchange parameters of Abies balsamea (L) Mill. and Abies concolor saplings, grown under various water regime, exposed to extreme drought stress at the end of the growing season. Turkish Journal of Forest Science, 5(2), 592-605

\section{ESER BILGISI / ARTICLE INFO}

Araştırma Makalesi / Research Article

Geliş 2 Eylul 2021 / Received 2 September 2021

Düzeltmelerin gelişi 6 Ekim 2021 / Received in revised form 6 October 2021

Kabul 8 Ekim 2021 / Accepted 8 October 2021

Yayımlanma 31 Ekim 2021 / Published online 31 October 2021

\begin{abstract}
Two-year-old (plug+1) containerized Abies balsamea (L) Mill. and Abies concolor seedlings were grown under various irrigation in the greenhouse to examine gas exchange parameters end of the growing period when they were exposed to extreme drought stress. Relative height growth (RHG) and relative root collar diameter (RRCD) were measured next to gas exchange parameters, such as net photosynthetic rate (Anet), stomatal conductance $(g s)$, transpiration rate $(E)$, intrinsic water use efficiency $(i W U E=A n e t / g s)$, and water use efficiency $(W U E=A n e t / E)$. As a result, $A$. balsamea seedlings had a higher RHG and RRCD than A. concolor. Species had a significant effect on leaf gas exchange parameters that $A$. balsamea had a higher Anet, gs, and a lower $i W U E$ than A. concolor. Increasing irrigation increased Anet and $E$. The interaction of species and time was statistically significant for gs and $i W U E$ measurement. İncreasing prolonged drought decreased $g s$ and did not change $i W U E$ values for $A$. balsamea, while increased $g s$ and reduced $i W U E$ for $A$. concolor seedlings. Even though Anet, $E$, and WUE were not statistically significant under the interaction of species and time, there is a decreasing trend for A. balsamea on these parameters. In contrast, A. concolor had a decreasing trend on Anet, and WUE and an increasing trend for $g s$ when the seedlings were exposed to extreme drought or extended the dehydration period were observed. $A$. balsamea had a better performance and drought tolerance than A. concolor when exposed to a prolonged drought.
\end{abstract}

Keywords: Abies balsamea, Abies concolor, net photosynthetic rate, stomatal conductance, water use efficiency. 


\section{ÇEŞITTLI SULAMA REJIMLERINDE YETIŞTIRILEN Abies balsamea VE Abies concolor FIDANLARININ BÜYÜME DÖNEMİ SONUNDA AŞIRI KURAKLIK STRESI ALTINDAKİ GAZ DEĞISŞIM PARAMETRELERİ}

ÖZET: Sera ortamında farklı sulama rejimleri altında yetiştirilen iki yaşında (plug+1) tüplü Abies balsamea ve Abies concolor fidanlarının büyüme dönemi sonundaki aşırı kuraklık stresine maruz bırakılmaları durumundaki gaz alışveriş parametreleri incelenmiştir. Net fotosentez (Anet), stoma iletkenliği $(g s)$, terleme oranı $(E)$, içsel (gerçek) su kullanım etkinliği $(i W U E=A n e t / g s)$ ve anlık bitki su kullanım etkinliği $(W U E=A n e t / E)$ yanında göreceli boy büyümesi (RHG) ve çap artımı (RRCD) ölçülmüştür. Sonuç olarak A. balsamea fidanları A. concolor göre daha fazla RHG ve RRCD büyümesi yapmıştır. Yaprak gaz alışveriş parametreleri üzerinde türlerin önemli bir etkisi olup, A. balsamea A. concolor göre daha yüksek Anet, gs ve daha düşük $i W U E$ değerlerine sahiptir. Artan sulama Anet ve E'yi artırmıştır. Tür ve ölçüm zamanı etkileşimi, $g s$ ve $i W U E$ değerleri üzerinde istatistiksel olarak anlamlı çıkmıştır. Kuraklık periyodunun uzaması A. balsamea fidanlarının gs değerlerini düşürmüş ve $i W U E$ değerleri değiştirmezken, $A$. concolor fidanlarında $g s^{\prime}$ yi artırmış ve $i W U E$ değerini düşürmüştür. Tür ve ölçüm zamanı etkileşimi altında Anet, gs ve WUE istatistiksel olarak anlamlı olmasa da bu parametreler A. balsamea fidanlarında azalma eğilimi göstermiştir. Aksine, fidanlar aşırı kuraklık stresine maruz kaldığında veya susuz dönem uzadığında, A. concolor fidanlarının Anet ve WUE değerlerinde bir azalan ve gs değerlerinde artan bir eğilim gözlemlenmiştir. A. balsamea uzun kuraklık dönemine maruz kaldığında $A$. concolor'a göre daha iyi bir performansa ve kuraklık toleransına sahiptir.

Anahtar kelimeler: Abies balsamea, Abies concolor, net fotosentez, stoma iletkenliği, su kullanım verimliliği.

\section{INTRODUCTION}

Among conifer species, Abies species (Fir ssp.) is an important genus of the Pinaceae family that consists of 48 species and 24 varieties, especially in the northern hemisphere, and distribute from Asia to Europe, Africa, and North and Middle America (Farjon, 2001). About ten fir species are found in the USA (Semerikova et al., 2018). Among them, Abies concolor subsp. concolor 'Cibola' and Abies balsamea (L.) Mill 'Cooks' are preferred to use for this study because of their economic importance, desirable color for ornamental value such as Christmas tree production, landscaping, and being a renewable resource (Koç, 2019; Cregg \& O'Donnell, 2020). A. balsamea is native to most of Canada and the northern United States (Frank 1990). Even though A. balsamea is slow-growing trees, it has been widely used for a Christmas tree due to their dark green needles and strong scent (Cregg, 2016). Unlike, A. concolor naturally occurs in the western United States, including Colorado, Utah, Idaho, Arizona, Nevada, and New Mexico, and has been widely distributed in the southern Rocky Mountains (Laacke, 1990). A. balsamea in its native range is grown in mesic sites compared to A. concolor species that they are some kinds of adaptation to xeric sites. In their natural distributed sites, $A$. balsamea 'Cooks' receives about $760-1100 \mathrm{~mm}$ precipitation while A. concolor 'Cibola' receives 520-890 mm precipitation (Frank, 1990; Laacke, 1990) which is considered moderately drought-tolerant (Wood, 2006). However, A. balsamea has a low drought tolerance (TreesForME, 2021). 
Morphological, anatomical, and phenotypic characteristics of plants result from environmental conditions (Koç, 2021a; Ozel et al., 2021). Among the environmental factors, water is an essential compound for all living organisms. Water plays a crucial role in plants for their seed germination (Koç, 2018), growth, development, and physiological processes such as carbon assimilation and photosynthesis (Koç, 2021b; Koç, 2021c), directly associated with the xylem water transport efficiency for terrestrial plants (Soba et al., 2020; Wang et al., 2020). The efficiency of water usage in plants may alter under different environmental stress. Water use efficiency is explained as the amount of water used to produce a unit of biomass or fixed carbon unit during photosynthesis (Maier et al., 2019). Water use efficiency is used as one of the key traits that reveal the physiological adaptation of plants to deal with water deficit conditions. The proportion of net photosynthetic rate and transpiration reflects water use efficiency, while the ratio of net photosynthetic rate and stomatal conductance indicates intrinsic water use efficiency in the leaf-level via gas exchanges (Lambers et al., 2010). Stricter stomatal control induces to enhance short-term (intrinsic water use efficiency) (Comstock, 2002) and long-term water use efficiency (de Miguel et al., 2012). These traits have been widely used to investigate the relationship between plant growth and physiology where plants are exposed to a water deficit situation.

Tree root plays a crucial role in water and nutrient uptake in plants (Fageria et al. 2016; Shults et al. 2020) and coping with environmental stressors (Seleiman et al. 2021). The state of the lack of water in the soil is called a water deficit or drought, which restricts various physiological processes in plants. A decline in plant turgor pressure triggers trees to close stomata to diminish transpiration under drought stress (Dayer et al., 2020; Yang et al., 2021). Drought has often been observed in many regions worldwide. Drought stress is crucial abiotic stressor limiting plant growth and physiology among environmental stresses (Sevik \& Erturk, 2015; Liet at al., 2020; Guo et al., 2021; Koç, 2021b; Koç, 2021 c). The frequency of drought events will likely be more common by the end of the $21^{\text {st }}$ century due to climatic warming from increased concentrations of greenhouse gasses (IPCC, 2014a; Varol et al., 2021). The increase in the frequency and intensity of droughts are more likely to be associated with a decrease in soil moisture (Xu et al., 2020). According to the future global climate change projection scenarios, the air temperature may increase $2.5{ }^{\circ} \mathrm{C}$ and $5.4{ }^{\circ} \mathrm{C}$ by 2050 and 2100 , respectively (IPCC, $2014 b)$. Increasing air temperature progresses the evaporation and may increase or decrease the precipitation in some regions. There will inevitably be some changes in the plants' gas exchange parameters in these changing temperatures and precipitation.

Among the measurement of needle gas exchange parameters, the Li-Cor portable photosynthesis system (Li-Cor Biosciences, Lincoln, NE, USA) has been commonly used for more than two decades due to providing robust results. With this instrument, it is obtained such as stomatal conductance, net photosynthetic rate, transpiration rate. The model of Li-Cor 6400XT is a closed system that controls $\mathrm{CO}_{2}$, relative humidity, IRGA, and light intensity, which provides robust and rapid simultaneous responses and excludes time delays. All gas exchange parameters are measured based on a unit area on the needle or leaves.

These two conifer species have been intensively planted as Christmas trees around the USA, especially in the Midwest and Eastern USA. Since they will continue to be used intensively in the future, it is crucial to know how they will react under a more extended period of drought stress, which is the most critical adverse effect of future climate changes. Species have various abilities to acclimate and survive under disparate hydraulic and water conditions (Allen et al., 2010) and gas exchange. By improving the understanding of gas exchange mechanism and 
responses to drought, farm managers will better be prepared for possible changes in reducing precipitation and lack of soil water status under future global warming events. This study aimed to investigate the effect of dehydrating the A. balsamea and $A$. concolor seedlings, which were subjected to various drought stress treatments during the growing period, on the gas exchanges of the seedlings at the end of the growing period.

\section{MATERIALS AND METHODS}

This experiment was conducted in an automatically controlled greenhouse at the Tree Research Center on the Michigan State University, USA. A double layer of clear plastic was used to cover the greenhouse. The average of minimum and maximum temperature was $27.04{ }^{\circ} \mathrm{C}$ and $15.45^{\circ} \mathrm{C}$ in the greenhouse during the measurement period (August 21 -September 18).

\section{Plant Material and Containerization Substrates}

Two-years old (plug+1) containerized A. balsamea (Balsam fir) (L.) Mill. 'Cooks' (New York), and A. concolor (Concolor fir) 'Cibola' (New Mexico) seedlings were obtained a commercial nursery (Vans Pine Nursery, West Olive, MI) on the first week of May. Then, they were transferred into 11.2-liter black cylindrical plastic containers with Fafard 52 potting mix (Conrad Fafard, Inc. Agawam, MA). The potting mix, pH range was 5.5 to 6.5 after wetting, consists of Canadian sphagnum peat moss (30\%), vermiculite, perlite, processed pine bark, dolomitic limestone and wetting agents. A total of 120 seedlings were potted into containers and well-watered until mid-July. $60 \mathrm{~g}$ of granular fertilizer (Osmocote Plus 15-9-12 [N, P, K], 5-6 month controlled-released) (Everris NA Inc, Dublin, $\mathrm{OH}$ ) was applied as top dress in the beginning of June.

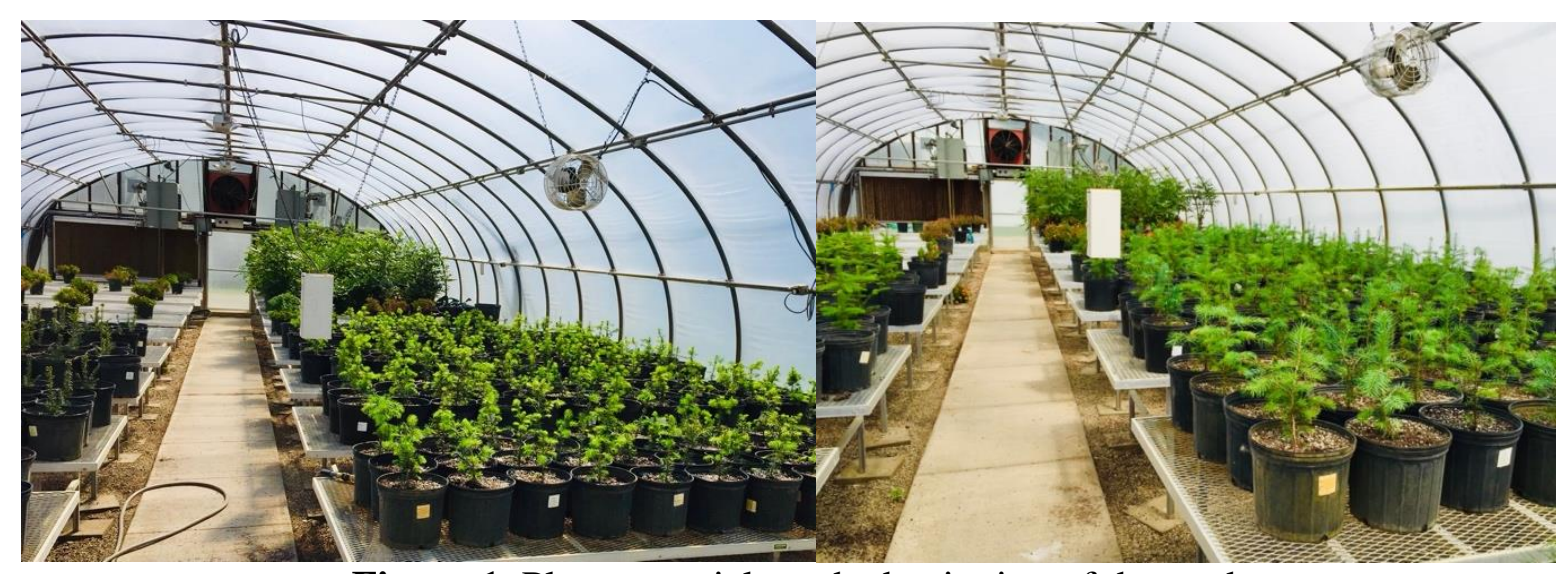

Figure 1. Plant materials at the beginning of the study

The initial root collar diameters $( \pm$ S.D) were $4.48( \pm 0.65), 5.14( \pm 0.99) \mathrm{mm}$ and heights $( \pm$ S.D) were $21.76( \pm 2.25), 25.48( \pm 2.57) \mathrm{cm}$ for A. balsamea and A. concolor, respectively.

\section{Irrigation Treatment}

At the beginning of the irrigation treatment, five containerized seedlings from each species were used to decide plants' water requirements as the following procedure. The ten wellwatered containers were allowed to drain gravitationally for 2 hours and weighted. The containers were weighted again a week later. The difference between initial and final weight 
was how much water seedlings were used weekly. Irrigation treatments were then established at 100,50 , and $25 \%$ of the water requirement as determined above.

Irrigation treatments were then established at the 100,50 , and $25 \%$ of determining water usage corresponding to three irrigation volumes: High=Well-watered $(3000 \mathrm{~mL})$, medium $(1500$ $\mathrm{mL})$, and low $(750 \mathrm{~mL})$. The irrigation volumes were applied manually from June $19^{\text {th }}$ to August $21^{\text {st }}$, for about nine weeks, and then the irrigation treatments were terminated.

\section{Relative Root Collar Diameter (RRCD) and Relative Height Growth (RHG)}

Root collar diameter and stem height were measured at the beginning and end of the experimental period. A digital caliper and tape measurer were used to measure root collar diameter and stem height of seedlings, respectively. Root collar diameter was measured at the soil surface. Relative root collar diameter (RRCD) and relative height growth (RHG) was calculated as the difference between the end of the growth period and the initial measurement divided by initial values.

\section{Gas Exchange Measurement}

In this study, randomly selected four seedlings from each treatment were used on gas exchange measurements using Li-Cor conifer chamber (LI-6400XT, Lincoln, NE, USA) with an attachment of the RGB (Red, Green, Blue) light source (640-18A). The calibration procedure was done before each measurement as suggested by the manufacturer. Then reference $\mathrm{CO}_{2}$ and the photosynthesis photon flux density (PPFD), and the airflow rate set and maintained 400 $\mu \mathrm{mol} \mathrm{mol}{ }^{-1} \mathrm{~s}^{-1}, 500 \mu \mathrm{mol} \mathrm{s}{ }^{-1}, 500 \mu \mathrm{mol} \mathrm{s}{ }^{-1}$, respectively. Four seedlings were randomly chosen from each treatment, and three readings were taken on each seedling on the two measurement days (September 4 [14 days of the dehydration] and September 18 [28 days of the dehydration]. The needle-leaves used to take measurements from each seedling were scanned and determined projected leaf area using the ImageJ software program (Rasband, 2016). The obtained needleleaf areas were then entered as a section in the Li-Cor system to adjust gas exchange parameters earlier measured in the greenhouse for the specimen.

Several gas exchange variables, especially the net photosynthetic rate (Anet, $\mu \mathrm{mol} \mathrm{m} \mathrm{m}^{-2} \mathrm{~s}^{-1}$ ), stomatal conductance $\left(g s, \mu \mathrm{mol} \mathrm{H}_{2} \mathrm{O} \mathrm{m}^{-2} \mathrm{~s}^{-1}\right)$, transpiration rate $\left(E, \mathrm{mmol} \mathrm{m}{ }^{-2} \mathrm{~s}^{-1}\right)$, intrinsic water use efficiency $(i W U E=A n e t / g s)$ and water use efficiency $(W U E=A n e t / E)$ were instantaneously measured and calculated by the LI-6400XT software.

\section{Statistical Analysis}

A complete randomized design was used with two species, three drought stress levels, two measurement times, and ten seedlings for each treatment of water stress (considered as replication), and a total of 120 containerized seedlings were used in this study. SAS 9.1 software (SAS Institute Inc., Cary, NC, USA) was used to analyze data. All gas exchange parameters were tested for normality using PROC UNIVARIATE. PROC MIXED function was used to conduct an analysis of variance (ANOVA) for all the variables. Tukey's adjustment was used to mean separation of species, treatment, and time factor for all gas exchange parameters. The relations between gas exchange variables were determined by linear and logarithmic regression. 


\section{RESULTS}

\section{Relative Root Collar Diameter (RRCD) and Relative Height Growth (RHG)}

A. balsamea statistically had a higher RRCD and RHG compared to A. concolor. A. balsamea and $A$. concolor seedlings had $0.66 \pm 0.01$ and $0.57 \pm 0.01 \mathrm{~mm}$ growth on RRCD when $0.35 \pm 0.01$ and $0.30 \pm 0.01 \mathrm{~cm}$ growth on RHG, respectively. Increasing irrigation increased RRCD that well-watered treatments had higher RRCD growth compared to medium and low watered seedlings for both species. Increasing irrigation increased the RHG for A. balsamea, while increasing in irrigation did not affect RHG for $A$. concolor.

\section{Gas Exchange Parameters at The Needle-Leaf Level}

The statistical analysis of variance for Anet, $g s, E, i W U E$, and WUE among two species, three drought stress, and two measurement times are given in Table 1.

Table 1. Degrees of Freedom (df), F-values of Analysis of Variance for Anet, gs, E, iWUE, and WUE Among Two Species, Three Drought Stress, and Two Measurement Times.

\begin{tabular}{|c|c|c|c|c|c|c|}
\hline Source of variation & df & Anet & $g s$ & $E$ & $i W U E$ & WUE \\
\hline \multicolumn{7}{|l|}{ Between subjects } \\
\hline Species (S) & 1 & $3.95 *$ & $49.69 * * *$ & $1.84 \mathrm{~ns}$ & $159.71 * * *$ & $0.29 \mathrm{~ns}$ \\
\hline Irrigation (I) & 2 & $12.73 * * *$ & $2.20 \mathrm{~ns}$ & $4.47 *$ & $1.74 \mathrm{~ns}$ & $0.83 n s$ \\
\hline Time $(\mathrm{T})$ & 1 & $106.35 * * *$ & $2.61 \mathrm{~ns}$ & $0.03 \mathrm{~ns}$ & $76.37 * * *$ & $23.53 * * *$ \\
\hline \multicolumn{7}{|l|}{ Within subjects } \\
\hline SxI & 2 & $0.30 \mathrm{~ns}$ & $0.90 \mathrm{~ns}$ & $0.35 \mathrm{~ns}$ & $0.24 \mathrm{~ns}$ & $1.05 \mathrm{~ns}$ \\
\hline SxT & 1 & $0.18 \mathrm{~ns}$ & $47.77 * * *$ & $2.81 \mathrm{~ns}$ & $100.84 * * *$ & $0.88 \mathrm{~ns}$ \\
\hline IxT & 2 & $2.58 \mathrm{~ns}$ & $1.48 \mathrm{~ns}$ & $0.01 \mathrm{~ns}$ & $1.30 \mathrm{~ns}$ & $2.44 \mathrm{~ns}$ \\
\hline SxIxT & 2 & $3.31 *$ & $0.11 \mathrm{~ns}$ & $0.40 \mathrm{~ns}$ & $4.35^{*}$ & $0.62 \mathrm{~ns}$ \\
\hline
\end{tabular}

Note: * significant at 0.05 level. *** Significant at 0.001 level. ns: not significant.

The mean values and Tukey's test results of Anet rate in terms of the interaction of species, irrigation level, and time are presented in Table 2. 
Table 2. The Mean of Anet Rates $\left(\mu \mathrm{mol} \mathrm{m} \mathrm{m}^{-2} \mathrm{~s}^{-1}\right.$ By the Interaction of Species, Irrigation, and Time.

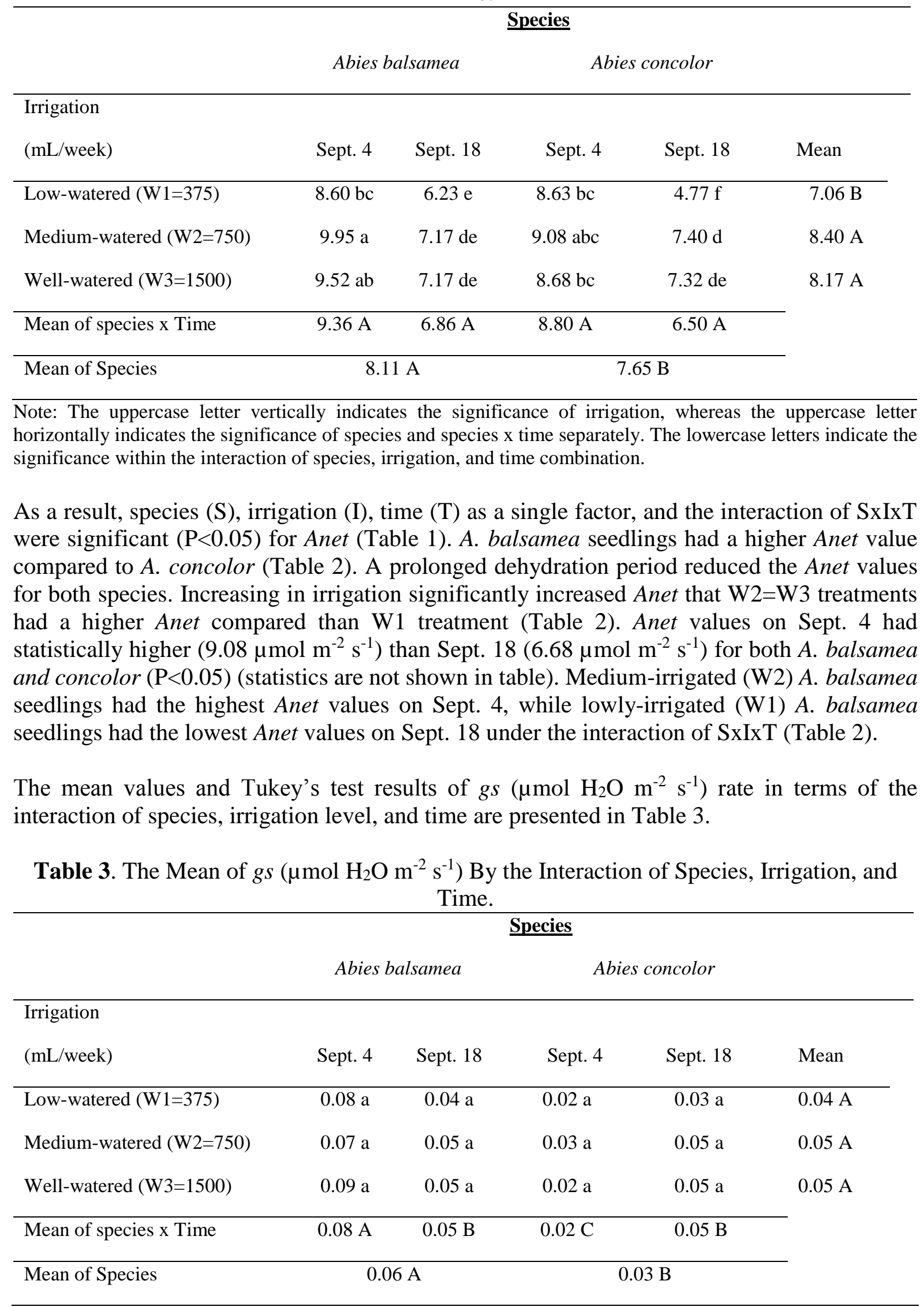


Note: The uppercase letter vertically indicates the significance of irrigation, whereas the uppercase letter horizontally indicates the significance of species and species x time separately. The lowercase letters indicate the significance within the interaction of species, irrigation, and time combination.

As a result, only $\mathrm{S}$ and SxI interaction were significant $(\mathrm{P}<0.05)$ on the $g s$ (Table 1$). A$. balsamea seedlings had a higher gs compared to A. concolor (Table 3 ). Under the SxT interaction, A. balsamea seedlings on Sept. 4 statistically had the highest $g s$ values, while the A. concolor seedlings on Sept. 4 had the lowest $g s$ values. As can be seen, a prolonged dehydration period decreased $A$. balsamea $g s$ values statistically while increasing $g s$ values for A. concolor (Table 3).

The mean values and Tukey's test results of $E\left(\mathrm{mmol} \mathrm{m}^{-2} \mathrm{~s}^{-1}\right)$ rate in terms of the interaction of species, irrigation level, and time are presented in Table 4.

Table 4. The Mean of $E\left(\mathrm{mmol} \mathrm{m}^{-2} \mathrm{~s}^{-1}\right)$ By the Interaction of Species, Irrigation, and Time.

\section{Species}

Abies balsamea

Abies concolor

\begin{tabular}{|c|c|c|c|c|c|}
\hline \multicolumn{6}{|l|}{ Irrigation } \\
\hline (mL/week) & Sept. 4 & Sept. 18 & Sept. 4 & Sept. 18 & Mean \\
\hline Low-watered $(\mathrm{W} 1=375)$ & $0.87 \mathrm{a}$ & $0.80 \mathrm{a}$ & $0.75 \mathrm{a}$ & $0.75 \mathrm{a}$ & $0.79 \mathrm{~B}$ \\
\hline Medium-watered $(\mathrm{W} 2=750)$ & $1.16 \mathrm{a}$ & $0.96 \mathrm{a}$ & $0.88 \mathrm{a}$ & $1.00 \mathrm{a}$ & $1.00 \mathrm{~A}$ \\
\hline Well-watered (W3=1500) & $1.21 \mathrm{a}$ & $0.97 \mathrm{a}$ & $0.93 \mathrm{a}$ & $1.05 \mathrm{a}$ & $1.04 \mathrm{~A}$ \\
\hline Mean of species $x$ Time & $1.08 \mathrm{~A}$ & $0.91 \mathrm{~A}$ & $0.85 \mathrm{~A}$ & $0.93 \mathrm{~A}$ & \\
\hline Mean of Species & \multicolumn{2}{|c|}{$0.99 \mathrm{~A}$} & \multicolumn{2}{|c|}{$0.89 \mathrm{~A}$} & \\
\hline
\end{tabular}

Note: The uppercase letter vertically indicates the significance of irrigation, whereas the uppercase letter horizontally indicates the significance of species and species $x$ time separately. The lowercase letters indicate the significance within the interaction of species, irrigation, and time combination.

Irrigation was significant $(\mathrm{P}<0.05)$ only on $E$, while the rest of the factors was not significant $(\mathrm{P}>0.05)$ (Table 1). Increasing irrigation increased seedlings' $E$ that $\mathrm{W} 3=\mathrm{W} 2$ had the higher values than W1 treatment (Table 4). It has not been determined that the prolongation of the dehydration period affects the seedling species $E$.

The mean values and Tukey's test results of $i W U E$ (Anet/gs) rate in terms of the interaction of species, irrigation level, and time are presented in Table 5. 
Table 5. The Mean of $i W U E$ (Anet/gs) (\%) By the Interaction of Species, Irrigation, and Time.

\begin{tabular}{|c|c|c|c|c|c|}
\hline \multicolumn{6}{|c|}{ Species } \\
\hline & \multicolumn{2}{|c|}{ Abies balsamea } & \multicolumn{2}{|c|}{ Abies concolor } & \\
\hline \multicolumn{6}{|l|}{ Irrigation } \\
\hline (mL/week) & Sept. 4 & Sept. 18 & Sept. 4 & Sept. 18 & Mean \\
\hline Low-watered $(\mathrm{W} 1=375)$ & $140.11 \mathrm{~d}$ & $172.92 \mathrm{~cd}$ & $415,00 \mathrm{a}$ & $155.85 \mathrm{~d}$ & $220.97 \mathrm{~A}$ \\
\hline Medium-watered (W2=750) & $148.57 \mathrm{~d}$ & $149.98 \mathrm{~d}$ & $368.09 \mathrm{ab}$ & $208.19 \mathrm{c}$ & $218.71 \mathrm{~A}$ \\
\hline Well-watered (W3=1500) & $135.81 \mathrm{~d}$ & $141.73 \mathrm{~d}$ & $340.29 \mathrm{~b}$ & $180.60 \mathrm{~cd}$ & $199.61 \mathrm{~A}$ \\
\hline Mean of species x Time & $141.50 \mathrm{C}$ & $154.88 \mathrm{C}$ & $374.46 \mathrm{~A}$ & $181.54 \mathrm{~B}$ & \\
\hline Mean of Species & \multicolumn{2}{|c|}{$148.19 \mathrm{~B}$} & \multicolumn{2}{|c|}{$278.00 \mathrm{~A}$} & \\
\hline \multicolumn{6}{|c|}{$\begin{array}{l}\text { Note: uppercase letter vertically indicates the significance of irrigation, whereas the uppercase letter horizontally } \\
\text { indicates the significance of species and species x time separately. The lowercase letters indicate the significance } \\
\text { within the interaction of species, irrigation, and time combination. }\end{array}$} \\
\hline \multicolumn{6}{|c|}{$\begin{array}{l}\text { The single factors such as } \mathrm{S} \text { and } \mathrm{T} \text { and the interaction of SxT and SxIxT were significant } \\
(\mathrm{P}<0.05) \text { on } i W U E \text { (Table } 1) \text {. The highest } i W U E \text { was observed in } A \text {. concolor compared to } A \text {. } \\
\text { balsamea. Time as a single factor was significant that the highest } i W U E \text { values were observed } \\
\text { on Sept. } 4(257.98 \%) \text { compared to Sept. } 18(168.21 \%) \text { (data are not shown in table). Under } \\
\text { the SxT interaction, A. concolor seedlings on Sept. } 4 \text { statistically had the highest } i W U E \text { values, } \\
\text { followed by the } A \text {. concolor seedlings on Sept. } 18 \text {, while } A \text {. balsamea seedlings on both dates } \\
\text { had the lowest } i W U E \text { values. Prolonged the dehydration period did not affect } A \text {. balsamea } \\
i W U E \text { values statistically while it decreased } i W U E \text { values for } A \text {. concolor (Table } 5 \text { ). The } \\
\text { highest } i W U E \text { was observed lowly watered (W1) A. concolor, while the lowest } i W U E \text { was } \\
\text { observed lowly watered } A \text {. balsamea on Sept. } 4 \text { under the SxIxT interaction (Table 5). }\end{array}$} \\
\hline \multicolumn{6}{|c|}{$\begin{array}{l}\text { The mean values and Tukey's test results of WUE (Anet/E) rate in terms of the interaction of } \\
\text { species, irrigation level, and time are presented in Table } 6 .\end{array}$} \\
\hline \multicolumn{6}{|c|}{ Table 6. The Mean of $W U E(A / E)(\%)$ By the Interaction o } \\
\hline 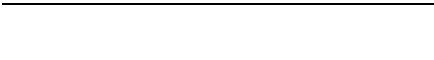 & \multicolumn{4}{|c|}{$\underline{\text { Species }}$} & \\
\hline & \multicolumn{2}{|c|}{ Abies balsamea } & \multicolumn{2}{|c|}{ Abies concolor } & \\
\hline \multicolumn{6}{|l|}{ Irrigation } \\
\hline (mL/week) & Sept. 4 & Sept. 18 & Sept. 4 & Sept. 18 & Mean \\
\hline Low-watered $(\mathrm{W} 1=375)$ & $11.94 \mathrm{a}$ & $7.80 \mathrm{a}$ & $11.73 \mathrm{a}$ & $7.11 \mathrm{a}$ & $9.65 \mathrm{~A}$ \\
\hline Medium-watered (W2=750) & $10.47 \mathrm{a}$ & $7.60 \mathrm{a}$ & $10.60 \mathrm{a}$ & $10.27 \mathrm{a}$ & $9.73 \mathrm{~A}$ \\
\hline Well-watered (W3=1500) & $10.26 \mathrm{a}$ & $7.69 \mathrm{a}$ & $9.68 \mathrm{a}$ & $8.14 \mathrm{a}$ & $8.94 \mathrm{~A}$ \\
\hline Mean of species $x$ Time & $10.89 \mathrm{~A}$ & $7.69 \mathrm{~A}$ & $10.67 \mathrm{~A}$ & $8.51 \mathrm{~A}$ & \\
\hline Mean of Species & \multicolumn{2}{|c|}{$9.29 \mathrm{~A}$} & \multicolumn{2}{|c|}{$9.59 \mathrm{~A}$} & \\
\hline
\end{tabular}


Note: The uppercase letter vertically indicates the significance of irrigation, whereas the uppercase letter horizontally indicates the significance of species and species x time separately. The lowercase letters indicate the significance within the interaction of species, irrigation, and time combination.

Time is the only factor that was significant on $W U E$ (Table 1) that the highest mean values were observed on Sep. 4 (10.78\%) compared to Sept. 18 (8.10\%). The highest WUE values are observed in an early stage of dehydration (14 days) in the late growing season, and progressive dehydration on plants reduced the WUE for both species (Table 6).

\section{DISCUSSION}

\section{Drought Stress Effect on RRCD and RHG}

Under water deficit conditions, plants have various mechanisms to alleviate their effect, resulting in plant growth and development restriction (Topacoglu et al., 2016; Koç, 2019; Yigit et al., 2019; Liu et al., 2020; Koç, 2021b: Koç, 2021c; Seleiman et al. 2021). Some plants tend to increase root growth such as pine species (Koç, 2019; Ding et al., 2020), but some plants tend to increase height growth, such as fir species, under unfavorable conditions (Gower et al. 1992; Pang et al., 2018). A. balsamea seedlings had a higher RRCD and RHG than A. concolor under each drought stress condition except for severe water stressed seedlings in this study. Under severe water-stressed (low-irrigated) treatment, A. balsamea seedlings had no statistical differences than $A$. concolor seedlings. Decreasing water availability reduces cell elongation, which results in reducing RRCD and RHG in plants.

\section{Water Stress Effect on Gas Exchange Parameters}

In the last decades, water stress has become the most unfavorable environmental factor for plant growth and physiology worldwide (Seleiman et al., 2021). Water availability plays a crucial role in every physiological process directly or indirectly in plants, including gas exchanges. Progressing water stress inhibits seedling gas exchange parameters (Koç, 2021b, Koç, 2021c). In general, decreasing water availability in the soil decreases xylem pressure potential resulting in a decline in $g s$, Anet, and $E$ in plants in line with the current study. A decrease occurs in the protective cell turgor due to the reactions occurring in the leaf cells of the coniferous species under water stress. Thus, the stomatal apertures are reduced or closed that $g s$ regulate the Anet and $E$. The reduction of stomatal aperture declines $\mathrm{CO}_{2}$ assimilation under water stress (Song et al., 2020). The stomatal closure is achieved by a decreasing water potential and increasing hormonal concentration such as abscisic acid (Hsu et al., 2021) in coniferous species (Brodribb \& McAdam, 2013). The reduction of stomatal aperture results in decline in $g s$, Anet, and $E$ is observed in other conifer species such as Pinus ssp., and A. ssp. (Zweifel et al., 2009; Hart et al., 2020).

In contrast, decreasing water availability in the soil generally increases $i W U E$ and $W U E$ for $A$. balsam and A. concolor. Trees can achieve high $i W U E$ either due to high Anet values and low stomatal conductivity or under the influence of both (Koç, 2019; Koç, 2021b, Koç, 2021c). Decreasing $g s$ in the leaf will reduce the amount of $E$; thus, this will positively affect $W U E$ in plants (Belmecheri et al., 2021) in line with the present study. When plants are exposed to water stress, they tend to use water more efficiently to increase growth (Li et al., 2020; Liu et al., 2015). Under water stress conditions, plants with higher $i W U E$ and $W U E$ values result in better growth and productivity (Xu et al., 2020). 
Increasing the water stress intensity on plants tends to reduce $g s$, Anet, $E$ while increasing $i W U E$ and $W U E$ to alleviate or acclimate to water stress conditions. Seedlings who were exposed to 14 days no watering period had a higher Anet, gs, $E$, and $W U E$ and a lower $i W U E$ for A. balsamea when a higher Anet, $i W U E$, and WUE for A. concolor compared to seedlings who exposed to 28 days no watering period. Under 14 days no watering period, highly irrigated seedlings had a higher Anet, $g s, E$ than other watering treatment for both species in this study. Stomatal behavior plays a critical role in the balance between Anet and gs, and Anet and $E$ (Koç, 2021b, c) resulting the higher or lower $i W U E$ and $W U E$ in plants (Urban et al., 2017). In the present study, with the increase of the dehydration period, A. balsamea further increased leaf stomatal control, while stomatal control decreased in A. concolor. This stomatal control has increased the $i W U E$ values from A. balsamea with the prolongation of the dehydration period. A. concolor had the opposite trend.

\section{CONCLUSION AND SUGGESTIONS}

Water is an essential element for all living things. In the lack of water, negativities occur in plants' growth, development, and gas exchange. Some tree species are less affected by water scarcity because of mechanisms they have developed against water scarcity. The prolongation of the dehydration period affects tree species that do not have well-development protective mechanisms against water stress, and the effects of water stress can detect using gas exchange measurements. As a result of the gas exchange measurements, the A. balsamea species has applied a more successful strategy than $A$. concolor by closing its stomata earlier, and a stricter stomatal control results in reducing transpiration rate and increasing water use efficiency. The height and diameter growth results support that $A$. balsamea performs better than $A$. concolor. The adverse effects of water stress will be less with A. balsamea compared to A. concolor.

The current study results should be supported by future studies focusing on below-ground parts of the species. When trees have a robust root system, they can alleviate water stress by using a different mechanism. The genetic variation, root type, length, ratio of the finer roots, and root to shoot ratio are crucial for plant growth, development, and physiology under unfavorable conditions. Furthermore, the leaf type and stoma length are the other factors to be focused on in the future. Future studies are necessary to test fir species that naturally occurs in Turkey. Future studies will increase our knowledge and provide some information to growers and practitioners.

\section{REFERENCES}

Allen, C. D., Macalady, A. K., Chenchouni, H., Bachelet, D., McDowell, N., Vennetier, M., \& Cobb, N. (2010) A global overview of drought and heat-induced tree mortality reveals emerging climate change risks for forests. Forest Ecology and Management, 259(4), 660-684.

Belmecheri, S., Maxwell, R. S., Taylor, A. H., Davis, K. J., Guerrieri, R., Moore, D. J., \& Rayback, S. A. (2021) Precipitation alters the CO2 effect on wateruse efficiency of temperate forests. Global Change Biology, 27(8), 1560-1571.

Brodribb, T. J., \& McAdam, S. A. (2013) Abscisic acid mediates a divergence in the drought response of two conifers. Plant Physiology, 162(3), 1370-1377. 
Comstock, J. P. (2002) Hydraulic and chemical signalling in the control of stomatal conductance and transpiration. Journal of Experimental Botany, 53(367), 195-200.

Cregg, B. M., \& O’Donnel, J. (2020) Real Christmas trees: Which one is right for you. https://www.canr.msu.edu/news/choosing_the_right_christmas_tree\#balsam/ Accessed 19.04.21.

Cregg, B. M. (2016). Choosing the right Christmas tree: Abies balsamea. https://www.canr.msu.edu/news/choosing_the_right_christmas_tree\#balsam/ Accessed 01.08.18.

Dayer, S., Herrera, J. C., Dai, Z., Burlett, R., Lamarque, L. J., Delzon, S\& Gambetta, G. A. (2020) The sequence and thresholds of leaf hydraulic traits underlying grapevine varietal differences in drought tolerance. Journal of Experimental Botany, 71(14), 4333-4344.

de Miguel, M., Sánchez-Gómez, D., Cervera, M. T., \& Aranda, I. (2012) Functional and genetic characterization of gas exchange and intrinsic water use efficiency in a full-sib family of Pinus pinaster Ait. in response to drought. Tree Physiology, 32(1), 94-103.

Ding, Y., Schiestl-Aalto, P., Helmisaari, H. S., Makita, N., Ryhti, K., \& Kulmala, L. (2020) Temperature and moisture dependence of daily growth of Scots pine (Pinus sylvestris L.) roots in Southern Finland. Tree Physiology, 40(2), 272-283.

Fageria, N. K., Gheyi, H. R., Carvalho, M. C. S., \& Moreira, A. (2016) Root growth, nutrient uptake and use efficiency by roots of tropical legume cover crops as influenced by phosphorus fertilization. Journal of Plant Nutrition, 39(6), 781-92. https://doi.org/10.1080/01904167.2015.1088020

Farjon, A. (2001) World checklist and bibliography of conifers. Royal Botanic Gardens, Kew. Frank, R. M. (1990) Abies balsamea (L.) Mill. balsam fir. Silvics of North America, 1, 26-35.

Gower, S. T., Vogt, K. A., \& Grier, C. C. (1992) Carbon dynamics of Rocky Mountain Douglasfir: influence of water and nutrient availability. Ecological Monographs, 62(1), 43-65.

Guo, Q., Li, X., Niu, L., Jameson, P. E., \& Zhou, W. (2021) Transcription-associated metabolomic adjustments in maize occur during combined drought and cold stress, Plant Physiology, 186(1), 677-695.

Hart, J., O'Keefe, K., Augustine, S. P., \& McCulloh, K. A. (2020) Physiological responses of germinant Pinus palustris and P. taeda seedlings to water stress and the significance of the grass-stage. Forest Ecology and Management, 458, 117647. https://doi.org/10.1016/j.foreco.2019.117647

Hsu, P. K., Dubeaux, G., Takahashi, Y., \& Schroeder, J. I. (2021) Signaling mechanisms in abscisic acid- mediated stomatal closure. The Plant Journal, 105(2), 307-321.

IPCC 2014a. Climate change 2014: Impacts, Adaptation and Vulnerability. Part A: Global and Sectoral Aspects. Contribution of Working Group II to the Fifth Assessment Report of the IPCC. Cambridge: Cambridge University Press.

IPCC 2014b. "Climate Change 2014 Synthesis Report Contribution of Working Groups I, II and III to The Fifth Assessment Report of The Intergovernmental Panel on Climate Change," R. K. Pachauri, L. A. Meyer, Eds., Core writing team. IPCC, Geneva, 2014.

Koc, I., \& Nzokou, P. (2018) Effects of water stress and cold treatments on the germination of two conifers (Pinus nigra and Pinus brutia) species from Turkey. Hortscience, 53(9), 259-259.

Koç, İ. (2019) Conifers Response to Water Stress: Physiological Responses and Effects on Nutrient Use Physiology. Ph.D. Dissertation, Michigan State University. 
Koç, İ. (2021a) Using Cedrus atlantica's annual rings as a biomonitor in observing the changes of $\mathrm{Ni}$ and Co concentrations in the atmosphere, Environmental Science and Pollution Research, 1-7. Doi:10.1007/s11356-021-13272-3

Koç, İ. (2021b) Examining seed germination rate and seedlings gas exchange performances of some Turkish red pine provenances under water stress. Düzce University Journal of Science \& Technology, 9(3), 48-60.

Koç, İ. (2021c) Examining seed germination rate and seedlings gas exchange performances of some Anatolian black pine under water stress. International Karabakh Applied Sciences Conference, IKSAD Global Publishing House, 112-120.

Laacke, R. J. (1990) Abies concolor (Gord. \& Glend.) Lindl. ex Hildebr. White fir. Silvics of North America, 1, 36-46.

Lambers, H., Chapin III, F. S., \& Pons, T. L. (2008) Plant Physiological Ecology. (2th ed.). New York: Springer Science \& Business Media.

Li, P., Zhu, Y., Song, X., \& Song, F. (2020) Negative effects of long-term moderate salinity and short-term drought stress on the photosynthetic performance of Hybrid Pennisetum. Plant Physiology and Biochemistry, 155, 93-104.

Liu, L., Li, D., Ma, Y., Shen, H., Zhao, S., \& Wang, Y. (2020) Combined application of arbuscular mycorrhizal fungi and exogenous melatonin alleviates drought stress and improves plant growth in tobacco seedlings. Journal of Plant Growth Regulation, 1-14.

Liu, Y., Xiao, J., Ju, W., Zhou, Y., Wang, S., \& Wu, X. (2015) Water use efficiency of China's terrestrial ecosystems and responses to drought. Scientific Reports, 5(1), 1-12.

Maier, C. A., Burley, J., Cook, R., Ghezehei, S. B., Hazel, D. W., \& Nichols, E. G. (2019) Tree water use, water use efficiency, and carbon isotope discrimination in relation to growth potential in Populus deltoides and hybrids under field conditions. Forests, 10(11), 993.

Ozel, H. B., Cetin, M., Sevik, H., Varol, T., Isik, B., \& Yaman, B. (2021) The effects of base station as an electromagnetic radiation source on flower and cone yield and germination percentage in Pinus brutia Ten. Biologia Futura, 1-7.

Pang, X.Y., Yuan, X.J., Wang, A., Li, M.H., Liu, X.L., Pan, H.L., Yu, F.H., \& Lei, J.P. (2020) Effects of simulated warming and functional group removal on survival and growth of Abies faxoniana seedlings. The Journal of Applied Ecology, 29(3), 687695. DOI: $10.13287 / \mathrm{j} .1001-9332.201803 .010$

[dataset] Rasband, W. (2016). ImageJ. Image Processing and Analysis in Java, Research Services Branch, National Institute of Mental Health, Bethesda, Maryland, USA. http://rsbweb.nih.gov/ij/index.html.

Seleiman, M. F., Al-Suhaibani, N., Ali, N., Akmal, M., Alotaibi, M., Refay, Y., Dindaroglu, T., Abdul-Wajid, H. H., \& Battaglia, M. L. (2021) Drought stress impacts on plants and different approaches to alleviate its adverse effects. Plants 10(2), 259.

Semerikova, S. A., Khrunyk, Y. Y., Lascoux, M., \& Semerikov, V. L. (2018) From America to Eurasia: a multigenomes history of the genus Abies. Molecular Phylogenetics and Evolution, 125, 14-28.

Sevik, H., \& Erturk, N. (2015) Effects of drought stress on germination in fourteen provenances of Pinus brutia Ten. seeds in Turkey. Turkish Journal of Agriculture-Food Science and Technology, 3(5), 294-299.

Shults, P., Nzokou, P., \& Koc, I. (2020) Nitrogen contributions of alley cropped Trifolium pratense may sustain short rotation woody crop yields on marginal lands. Nutrient Cycling in Agroecosystem, 117, 261-272. https://doi.org/10.1007/s10705-020-100688

Soba, D., Shu, T., Runion, G. B., Prior, S. A., Fritschi, F. B., Aranjuelo, I., \& Sanz-Saez, A. (2020) Effects of elevated [CO2] on photosynthesis and seed yield parameters in two 
soybean genotypes with contrasting water use efficiency. Environmental and Experimental Botany, 178, 104154.

Song, X., Zhou, G., He, Q., \& Zhou, H. (2020) Stomatal limitations to photosynthesis and their critical water conditions in different growth stages of maize under water stress. Agricultural Water Management, 241, 106330.

Topacoglu, O., Sevik, H., \& Akkuzu, E. (2016) Effects of water stress on germination of Pinus nigra Arnold. seeds. Pakistan Journal of Botany, 48(2), 447-453.

TreesForMe (2021) Abies balsamea, Abies balsamea (L.) Mill. http://www.treesforme.com/balsam_fir.html/ Accessed 19.04.21.

Urban, J., Ingwers, M. W., McGuire, M. A., \& Teskey, R. O. (2017) Increase in leaf temperature opens stomata and decouples net photosynthesis from stomatal conductance in Pinus taeda and Populus deltoides x nigra. Journal of Experimental Botany, 68(7), 1757-1767.

Varol, T., Canturk, U., Cetin, M., Ozel, H. B., \& Sevik, H. (2021) Impacts of climate change scenarios on European ash tree (Fraxinus excelsior L.) in Turkey. Forest Ecology and Management, 491, 119199.

Wang, Y. S. D., Yang, D., Wu, H. D., Zhang, Y. B., Zhang, S. B., Zhang, Y. J., \& Zhang, J. L. (2020) Overlapping Water and Nutrient Use Efficiencies and Carbon Assimilation between Coexisting Simple-and Compound-Leaved Trees from a Valley Savanna. Water, 12(11), 3037.

Wood, K. (2006) Drought-tolerant trees for Colorado landscapes. Ph.D. Dissertation, Colorado State University, USA

Xu, Y., Feng, Z., Shang, B., Yuan, X., \& Tarvainen, L. (2020) Limited water availability did not protect poplar saplings from water use efficiency reduction under elevated ozone. Forest Ecology and Management, 462, 117999.

Yang, Y. J., Bi, M. H., Nie, Z. F., Jiang, H., Liu, X. D., Fang, X. W., \& Brodribb, T. J. (2021) Evolution of stomatal closure to optimize water- use efficiency in response to dehydration in ferns and seed plants. New Phytologist, 230(5), 2001-2010.

Yigit, N., Cetin, M., Ozturk, A., Sevik, H., \& Cetin, S. (2019) Varitation of stomatal characteristics in broad leaved species based on habitat. Applied Ecology and Environmental Research, 17(6), 12859-12868.

Zweifel, R., Rigling, A., \& Dobbertin, M. (2009) Species- specific stomatal response of trees to drought-a link to vegetation dynamics? Journal of Vegetation Science, 20(3), 442454. https://doi.org/10.1111/j.1654-1103.2009.05701.x 